\title{
Kernos
}

Revue internationale et pluridisciplinaire de religion grecque antique

4 | 1991

Varia

\section{Evidence for an Early Date for the Cult of Cretan Zeus}

\author{
Edmund F. Bloedow
}

\section{(2) OpenEdition \\ Journals}

\section{Electronic version}

URL: http://journals.openedition.org/kernos/297

DOI: 10.4000/kernos.297

ISSN: 2034-7871

\section{Publisher}

Centre international d'étude de la religion grecque antique

Printed version

Date of publication: 1 January 1991

Number of pages: 139-177

ISSN: 0776-3824

Electronic reference

Edmund F. Bloedow, «Evidence for an Early Date for the Cult of Cretan Zeus », Kernos [Online], 4 | 1991, Online since 11 March 2011, connection on 01 May 2019. URL : http://journals.openedition.org/ kernos/297; DOI : 10.4000/kernos.297 
Kernos, 4 (1991), p. 139-177.

\section{EVIDENCE FOR AN EARLY DATE FOR THE CULT OF CRETAN ZEUS}

\section{Peak Sanctuaries and the Cult Associated with them}

The cult of Cretan Zeus must now be studied, at least in part, within the context of what have been called peak sanctuaries. Peak sanctuaries have long been known as a familiar aspect of Minoan culture and, in particular, of Minoan religion ${ }^{1}$. Indeed, significant conclusions have been reached in connection with them.

In the Aegean, peak sanctuaries appear to be restricted chiefly to the island of Crete ${ }^{2}$. Over fifty such sanctuaries are now said to exist, with

1 On peak sanctuaries, see J.L. MYREs, The Sanctuary Site of Petsofa, in ABSA, 9 (1902-1903), p. 356-387; Sir A. Evans, The Peak Sanctuary of Knossos and the 'Tomb of Zeus', in ID., The Palace of Minos at Knossos, I, London, 1921, p. 151-263. Subsequently, most of the groundwork in the field has been carried out by Paul FAURE (cf. $B C H, 80$ [1956], p. 95-103; 82 [1958], p. 485-515; 84 [1960], p. 189-220; 86 [1962], p. 36-56; 87 [1963], p. 493-508; 89 [1965], p. 27-63; 91 [1967], p. 114-150; 93 [1969], p. 174-213; 96 [1972], p. 389-426; 102 [1978], p. 629-640). This has been supplemented by the work of Costis DaVARAs at a number of sites (cf., for instance, C. Davaras, Anaskaphi MM Hierou Kophines Vrysinas Rethymnes, in AAA, 7 [1974], p. 210-213), and most recently by the extensive new excavations of Mrs. Alexandra KARETSOU at Mt Iouktas. For a general survey, summarising the evidence in the early 70 s, there is the study of B. RUTKOWSKI, Cult Places in the Aegean World, Warsaw, 1972 (Bibliotheca Antiqua 10), and, from a decade later, the short survey by A.A.D. PeATFIELD, The Topography of Minoan Peak Sanctuaries, in ABSA, 78 [1983], p. 273-279. Cf. also C. Davaras, Guide to Cretan Antiquities, Park Ridge, N.J., 1976, p. 245-248, and his map showing the (18) excavated peak sanctuaries (ibid, p. 261). Otherwise, there are discussions in A.B. СоОК, Zeus. A Study in Ancient Religion, II, 2, Cambridge, 1925, p. 939-945; B.C. DIETRICH, Some Light from the East on Cretan Cult Practice, in Historia, 16 (1967), 385413; M.P. NILsson, Minoan-Mycenaean Religion and its Survival in Greek Religion, Lund, 19502, p. 71-76; W. BURKERT, Greek Religion. Archaic and Classical, Oxford, 1985, p. 26-28.

2 Cf. A.A.D. Peatfield (supra n. 1), p. 273. PeatField considers several possibilities on the Greek mainland, but rejects them on the grounds that they are qualitatively different. Cf. also B. RUTKowski, The Cult Places of the Aegean, New Haven and London, 1986, p. 73-98 and 243-247. 
more expected to be identified ${ }^{3}$. They are thought to have originated in the district of Siteia, at the eastern extremity of the island ${ }^{4}$.

On the basis of the evidence from these many sites, attempts have been made to establish a general and comprehensive picture of such sanctuaries. Briefly, the following components have been isolated. A principal feature which has been noted in connection with the location of these sanctuaries has to do with their altitude, namely that most of them lie "within altitude regions associated with summer transhumance of sheep and goats'5.

The artifacts discovered at these sanctuaries include 'vast numbers of votive clay figurines of domestic farm animals'. This establishes 'the link between peak sanctuary cult and pastoral farming ${ }^{6}$, from which one can extrapolate that 'peak sanctuaries came into existence to relieve the fears and cares of the shepherds and cattie breeders' 7 .

It seems, however, that 'mountain pastures' may not have been the only factor involved. Another consideration is allegedly the distance from a given village to a peak sanctuary. The implication is that these villages represent year-round settlements, not seasonal occupation that would be associated with summer transhumance. Investigations into this question have shown that the average travel time from a given village to a peak sanctuary is about one hour ${ }^{8}$. Another factor in this context may have been 'the general prominence and viability' of a given

3 A.A.D. PeatField (supra n. 1), p. 273.

4 P. FAURE, in $B C H$, 93 (1969), p. 174-213; 96 (1972), p. 389-426; B. RUTKOWSKI (supra n. 1), p. 184-185; A.A.D. PEATFIELD (supra n. 1), p. 273.

5 A.A.D. Peatfield (supra n. 1), p. 273. Hutchinson too refers to transhumance, but does not associate it with peak sanctuaries (R.W. Hutchinson, Prehistoric Crete, Harmondsworth, 1968, p. 238).

6 A.A.D. PEATFIELD (supra n. 1), p. 273.

7 B. RUTKOWSKI (supra n. 1), p. 185. RUTKOWSKI refers to 'shepherds and cattlebreeders', 'cattle-breeders and shepherds', 'the rapid growth of sheep rearing', 'sheep breeders'. But he also includes 'the farmers', and then refers to 'the sheep and cattle-breeders and the agrarian farmers', and 'sheep and cattle and crops' (loc. cit.). Cf. ID. (supra n. 2), p. 93-94.

8 A.A.D. PeATfield (supra n. 1), p. 275. As PEATFIELd correctly notes, however, this suggestion by FAURE and RUTKOWSKI must represent the optimum length of time. He points out that, after allowance has been made for such things as fitness of the inhabitants, knowledge of the quickest route and the weather, a time of several hours is a more reasonable estimate. If one adds to these the steepness of the climb in most instances, even 'several hours' sounds rather generous, certainly in a number of instances. 
mountain ${ }^{9}$, although this seems to be true in only a limited number of cases.

One also speaks of 'the peak sanctuary cult'10, which implies a uniform or common character. On the other hand, a sacred hierarchy of peak sanctuaries has also been maintained ${ }^{11}$.

It is generally believed that peak sanctuaries emerged at the beginning of the MM period, and then came to 'an abrupt end soon after the close of the Middle Bronze Age'12.

The uniformity which allegedly emerges from the above should make it reasonably easy to determine the character of the deity worshipped in connection with the peak sanctuary cult. And so we hear that the object in the cult was to 'relieve the fears and cares of the shepherds and cattle herders'. From this, one may legitimately posit 'a god' as 'ruler of the heavens, as lord of all atmospheric phenomena, who could produce rain and strong, gusty winds'. Consequently, 'votive offerings in the form of animals were especially common in the peak sanctuaries', and so one sought 'the god's help, particularly in producing rain'13. Moreover, figurines of beetles, identifiable as Copris hispanus ${ }^{14}$, are particularly significant, since the life of Copris hispanus is 'absolutely connected with the existence of a flock of sheep,

9 A.A.D. PEATFIELD (supra n. 1), p. 275.

10 A.A.D. PEATFIELd (supra n. 1), p. 273-279.

11 J. Bintuiff, Natural Environment and Settlement in Prehistoric Greece, Oxford, 1977 (BAR Supplementary Series, 28), p. 145-170. This, however, appears to be an oversimplification, as it breaks down under detailed analysis. After a brief survey of certain modern traditions in rural Greece, which are authentic enough, the reader is taken back into the prehistoric period. Here, for Crete, BINTLIFF relies almost exclusively on FAURE's investigations, which he recapitulates briefly. Thereafter, he returns to the Greek mainland, proceeding here as he has done in connection with Crete. In place of specific evidence, which is cited essentially as an afterthought, BINTLIFF proceeds with such techniques as 'we suggest', 'it is suggested', 'we suspect', 'we believe', 'we feel justified in arguing', 'we postulate', 'we would contend', 'we maintain', 'we might expect', 'it seems', 'apparently', 'doubtless', 'appear', 'seems likely', 'could have', 'may in future be found', 'likely to have been', 'probably', 'might', 'seemingly', 'appear to have been', 'possible', 'conceivably', 'perhaps', 'almost certainly', etc., etc.-these in profusion within the space of a few pages. Furthermore, BINTLIFF takes virtually no account of chronology, except in the most general terms, despite the many subphases which are now recognised.

12 A.A.D. Peatfield (supra n. 1), p. 277.

13 B. RUTKowsKI (supra n. 1), p. 172, cf. ID. (supra n. 2), p. 90-91.

14 Cf. below, n. 33. 
the basic source of natural wealth in Crete'. Consequently, 'where there were copris beetles there were sheep as well'. As Rutkowski sees it, 'the inhabitants of ancient Crete believed that beetles (copris) brought good luck', that Copris hispanus 'must have been regarded as a representative of the Goddess who was the Protectress of earth and heaven'. And so, 'in bringing models of beetles... the supplicants were no doubt asking the goddess to multiply their flocks of sheep'15.

Although the above may be essentially correct so far as a general picture is concerned, it will be appropriate to draw attention to some of the difficulties which arise, as these have a direct bearing on the question of religion and cult.

The notion of transhumance, which forms one of the cornerstones of this picture, calls for particular attention. Rutkowski, for instance, actually divides the terrain in question into two main regions, which, in turn, he further divides into six sub-regions. These are as follows :

Region I : 0-650 m.

a) $0-350 \mathrm{~m}:$ Here the vegetation is 'luxuriant, and vines and other plants are cultivated'.

b) $350-650 \mathrm{~m}$ : The vegetation at this altitude is made up of 'sparse maquis and oak woods'.

Region II : $650-1900 \mathrm{~m}$.

a) $650-1000 \mathrm{~m}$ : The vegetation in this niche is 'maquis, Aleppo pine woods, cypresses and mulberry trees'. In addition, there is heavy rainfall in spring and autumn.

b) 1000-1300 $\mathrm{m}$ : This forms the 'upper transition zone', and here 'rain occurs at all times of the year, sometimes even in summer'. Moreover, 'arable farming is practised and in summer the sheep are brought to the higher pastures. At this altitude it is still possible to live all year round'.

c) $1300-1500 \mathrm{~m}:$ Here 'land is still cultivated sporadically'.

d) $1500-1900 \mathrm{~m}$ : At this altitude 'the ground is covered with snow for many months of the year and cultivation of cereals is not possible 16 .

15 B. RUTKOWSKI (supra n. 1), p. 175-179, cf. ID. (supra n. 2), p. 89-91.

16 B. RuTKowsKi (supra n. 1), p. 154-155 (cf. ID. [supra n. 2], p. 73-74). Of these, only Regions Ia and IIb would seem to be suitable for pasturage. For a discussion of climatic conditions, in which more subtle distinctions are made, cf. P. FAURe, La vie quotidienne en Crète au temps de Minos (1500 avant Jésus-Christ), Paris, 1973, p. 69-71, and 77-81. 
No peak sanctuaries are located in Regions IId or IIc, a few in $\mathrm{IIb}^{17}$, and more in $\mathrm{II}^{18}$, as well as a few in $\mathrm{Ia}^{19}$. This puts the majority in $\mathrm{Ib}^{20}$.

The significance of this is allegedly that 'all peak sanctuaries, irrespective of height, are associated with regions that allow for some sort of farming, arable or pastoral, often both'21. And all of this is highly important in respect of attempting to determine the nature of the deity (or deities) worshipped in connection with peak sanctuaries.

As already noted above, the chief factor allegedly involved in relieving the fears and cares of shepherds and herders (and presumably agriculturalists as well) was rain. To secure the necessary rain, one appealed to 'the god or goddess'22. It is interesting that Rutkowski here regards the deity in question as a god or goddess. It should probably be of some importance to establish just which. Although initially he appears to

17 For instance, Karphi (1148 m), Kastellos (1160 m), Keria (1168 m), cf. A.A.D. Peatfield (n. 1), p. 274. Keria appears to be the highest peak sanctuary.

18 For instance, Iouktas (780 m), Kophinas $(970 \mathrm{~m})$, Plagia $(819 \mathrm{~m})$, Pyrgos (685 $\mathrm{m})$, Vigla (714 m), Vrysinas (858 m), Xykephalo (705 m), Zou (725 m) (cf. B. RUTKOWSKI [supra n. 1], p. 155, n. 7). DAVARAS, incidentally, places Kophinas at 1231 metres (C. DAVARAS [supra n. 1], p. 248), but this presumably refers to the highest ridge of the Asterousia Mountains, lying immediately to the south of the peak sanctuary.

19 The lowest peak sancturay appears to be Petsopha $(215 \mathrm{~m})$.

20 RUTKowsKI actually puts the majority between 350 and $800 \mathrm{~m}$ (B. RUTKOWSKI [supra n. 1], p. 172), which would mean an overlap between Region Ib and IIa. RUTKOWSKI's scheme is essentially artificial, especially the ascription of specific altitudes. There are variations from one region to another, and there is also considerable overlapping. It may be useful to compare his scheme with HuTchINSON's division, in which no specific altitudes are given :

a) Fertile coastal plains and valleys.

b) Mountain-locked upland plains, sometimes drained by a river but often drained by only natural swallow holes. Often snow-bound in winter and sometimes waterlogged if the swallow holes become blocked.

c) Low hills and table-land, providing good pasture and even arable land.

d) Forests.

e) The [Madara] bare lands on the higher mountains, providing summer pasturage but snowbound in winter.

f) The high peaks, crags and torrents that are unsuit able for pasture. (R.W. Hutchinson (supra n. 1), p. 37). Neither RUTKowski nor Hutchinson, however, give any special regional distribution of these vertical variations. 
place the god first ('the god as ruler of the heavens, as lord of all atmospheric phenomena') ${ }^{23}$, a little later we are presented with 'a Great Goddess', who takes precedence over 'a minor male divinity', the latter also worshipped 'at the time that sanctuaries were erected on the peaks'24.

If one, for instance, considers transhumance in light of this, a major difficulty appears to arise. Transhumance ostensibly takes place because there is no rain in the summer, with the result that pasture burns up at the low or lowest altitudes ${ }^{25}$. Consequently, shepherds and herdsmen move to higher pastures - but not because it rains at these altitudes in summer ${ }^{26}$, rather because here the water arrives later from the snows which melt higher up or the districts are fed by upland springs, and also because of the greater autumn and spring rains, so that the grass lasts longer. Indeed the small upland valleys where the summer grass was available provided pasturage, not because of summer rain, but because (in, for instance, the Siteia) they were 'watered by the springs from the mountains that enclose them'27. In this Siteia region, in the extreme east of the island (the district which Peatfield selects for detailed description as it provides the characteristic features of peak sanctuaries), such springs will have been fed chiefly by the autumn and spring rains, since the mountains here are not high enough for much, if any, snow. The continuous annual repetition of this phenomenon of

23 Loc. cit.

24 B. RUTKOWSKI (supra n. 1), p. 179. Did the prospects of the local inhabitants probably not obtaining much rain from such 'a minor male divinity' perhaps lead to the notion of 'a Great Goddess'? For a slight modification of this view, cf. ID. (supra n. 2), p. 91.

25 HUTCHINSON observes that the climate in Crete today 'varies greatly according to altitude', and refers specifically to 'the plains', where 'practically all the rain falls between October and March, usually some heavy rain in October and again in February or March' (R.W. HuTCHINSON [supra n. 5], p. 38).

26 RUTKowsKI makes the point that in his Region IIb, where he locates 'the higher pastures', 'rain occurs at all times of the year, sometimes even in summer' (B. RUTKOWSKI [supra n. 1], p. 155). Although this statement is somewhat ambiguous, it at all events leaves little doubt that there was very little, if indeed any, rain at this altitude in the summer. And at all events, it is above the line in which most of the peak sanctuaries are located, and those located at such an altitude are connected with human activity at a lower altitude. Certainly RUTKOWSKI does not connect a single peak sanctuary specifically with such an environmental niche.

27 A.A.D. PEATFIELd (supra n. 1), p. 274. 
nature must have eliminated from the native inhabitants any prospect of changing it by means of appealing to a deity. By the same token, they will presumably have seen little need of attempting to influence the autumn and spring rains, since they were such a regularly recurring phenomenon. The same presumably applies even more to Rutkowski's Region $\mathrm{Ib}$, into which most of the peak sanctuaries fall ${ }^{28}$. Otherwise, there is the possibility that in the MM and LM periods 'the island was greener... because there was more rain'29. It therefore looks as if the idea of a rain cult is based on very tenuous evidence.

28 In RUTKOWSKI' Region IIa, into which some of the peak sanctuaries fall, there was heavy rainfall in spring and in autumn. This was presumably true to at least some degree also in his Region Ib.

29 P. FAURE (supra n. 16), p. 70-71, and 77-81. Cf. : 'Minoan Crete therefore had more forest, was greener, received more rain and was surrounded by a sea that was cooler by one or two degrees, so that there was probably not the same acute shortage of fresh water that there is today' (ibid., p. 72). On the other hand, FAURE maintains that Dictynna, one of the principal deities of the Minoan world, the forerunner of Artemis and the Nymphs of the Greek world and the modern Nereids, was a goddess of gushing water', and sees a continuity between then and now in the current custom in the villages of the Ennea Choria, ancient Inachorium (Kisamou), where, if the population does not on May 6 celebrate properly the Festival of Saint Dikaios on Mt Dikaios (ancient Dictaios ?), there will not be any rain in the following year, or, in the words of the locals, sthe fountains will not open up"' (P. FAURE [supra n. 16], p. 73). While this may be suggestive enough, it should be borne in mind that there still seems to be a good deal of uncertainty about Dictynna. Persson, for instance, regarded her as 'closely associated with Britomartis' (A.W. PERSSON, The Religion of Greece in Prehistoric Times, Berkeley and Los Angeles, 1942, p. 128), and NiLsSON, who investigated the problem in great detail, expressed the view that 'It appears that she was a Cretan goddess very much resembling Artemis and parallel to Britomartis, but venerated in western Crete, whilst Britomartis was worshipped in eastern Crete', and that 'the close affinity of this Cretan goddess to Artemis and to Britomartis is evident' (M.P. NiLSSON [supra n. 1], p. 511, 512). PERSson, citing Mingazzini, thought that she originated in eastern Crete but was later forced to move elsewhere, namely, to western Crete (A.W. PERsson [this n.], p. 129, cf. M.P. NiLsSon [supra n. 1], p. 511-512). This makes it all the more difficult to be specific about the real character of Dictynna, i.e., if she had a distinctly separate identity. (It is perhaps worth noting that NILSSON does not speculate on this question.) Consequently, the idea of Dictynna as the 'goddess of gushing water' appears to be based on very tenuous evidence, as does the thesis that contemporary customs in the villages of Ennea Choria have a direct link with Bronze Age Crete. The latter is of course possible, but extremely difficult to demonstrate. WILLETTS notes that 'Continuous deforestation throughout the centuries has turned Crete, once one of the most fertile and prosperous islands in the 
A closer look at Rutkowski's arguments for sheep produces essentially the same results. His appeal to the beetles as evidence to substantiate this aspect of his thesis is far from compelling. If, for instance, a flock of sheep represented 'the basic source of material wealth in Crete', and if by bringing models of beetles 'the supplicants were no doubt asking the goddess to multiply their flocks of sheep ${ }^{30}$, should one not expect to find many more such artifacts, at many more sites $^{31}$ ? Apart from these considerations, there appear to be difficulties in identifying the artifacts in question as beetles ${ }^{32}$, and the beetles as Copris ${ }^{33}$.

The problem concerning sheep can, however, be approached in a different manner. Chadwick has drawn attention to Killen's brilliant research in connection with the Linear B tablets on sheep, according to which it was possible to determine that not only were sheep reared chiefly for wool, but also that at a given time there was a total of 'close to $100,000^{34}$. Although this circumstance seems to reflect concentration in central (northern) Crete, centred around the palace of Knossos, and dates from the LM (III) period, is it possible to see this as a continuation of an essentially similar state of affairs from an earlier era, except under altered conditions of organisation? In other words, is it possible to extrapolate from this a significant concentration in sheep already in the MM period, when the rearing of sheep was on the basis of private ownership, whereas in the Late Palace period it had become a state monopoly ? And could such a state monopoly have extended into the

Mediterranean, into one of the rockiest and most barren. When there were plenty of trees on the lower mountain slopes, water could be absorbed into the soil and so provide a natural reserve in dry seasons' (R.F. WILLETTS, The Civilization of Ancient Crete, London, 1977, p. 28 : my emphasis).

\section{' $R$ h} Ancient Crete, New York, 1971, p. 43) - a view with which RuTKowsKI took issue : 'It is most interesting to note that Mr. MroczKowsKI, a Polish entomologist consulted in 1966, said, almost without hesitation, after seeing photographs of the finds from Prophetis Elias, Petsopha, Piskokephalo and Palaikastro, that the models of beetles there could not be models of oryctes nasicornis (as has generally been supposed), but solely are of the scaraboid species, copris hispanus' (B. RUTKowSKI [supra n. 1], p. 176; cf. ID. [supra n. 2], p. 89).

34 J. CHADwick, The Mycenaean World, Cambridge, 1976, p. 127-129. 
mountainous region of Siteia as well ${ }^{35}$ ? That is to say, may in the period of private ownership the peak sanctuaries reflect the cares and concerns of the population in conjunction with their livelihood, whereas during the period of state monopoly the flocks and herds had become the care and concern of others? And may the cares and concerns of the people in the earlier period have been somewhat wider in scope than Rutkowski portrays?

In turning to the finds at these sanctuaries, Rutkowski divides them into three categories : human figurines, animal figurines and miniature objects. Of these, figurines of animals appear to be 'the most numerous', with the majority being 'domestic animals reared as stock' : 'cattle and pigs - mainly bulls, oxen, rams and sheep'36. The most striking, and at the same time the most important, aspect about the finds is that at virtually all peak sanctuaries they are almost invariably of a very modest character, so that very few aspire to any significant artistic merit. This would seem to leave little doubt that the individuals associated with the peak sanctuaries were essentially peasant folk, as Faure, Rutkowski and others have maintained. The equally modest nature of the architectural remains which have been discovered at these sites also bears this out ${ }^{37}$.

\section{The Peak Sanctuary of Mt Iouktas : Evans' Interpretation}

All this is of great importance, because it has a direct bearing on the religious significance of these sanctuaries, a question which is still not resolved. What Davaras wrote in 1976 , is still true today, namely that 'The nature of the deity or deities worshipped at peak sanctuaries remains a subject of discussion among scholars' 38 . From the essen-

35 Might such a state monopoly (in not only sheep farming) perhaps also account for, at least in part, the decline in peak sanctuaries in the LM period?

36 B. RUTKowsKI (supra n. 1), p. 170-171, cf. ID. (supra n. 2), p. 87.

37 It may be worth while pointing out that at some peak sanctuaries there are modern equivalents, namely in the form of very simple chapels (cf., for instance, Zou, Gonies and Vrysinas), also associated with the local peasant folk today. The simplest such modern example I saw was at Kophinas, which, interestingly, was on the highest ridge, at a height $(1231 \mathrm{~m})$ considerably above that of the ancient sanctuary $(970 \mathrm{~m})$, and much more difficult to reach. It was built of the abundant stones lying all over the top of the ridge. Its modest character was further underlined by the fact that it was not painted white, as were all the others. The local population clearly do not often make the difficult climb from the village of Kapetaliana to this barren peak.

38 C. DaVaras (supra n. 1), p. 248. 
tially uniform character of the evidence at virtually all the peak sanctuaries, one is inclined to conclude that the same deity ought to have been venerated at all of them. As we have already seen above, however, the identification of this deity is no easy matter. This is illustrated even more emphatically by the peak sanctuary on Mt Iouktas, and it is to this site that we must now turn.

The early investigation and interpretation of this peak sanctuary was bound up very much with the personality of Sir Arthur Evans and his reconstruction of Minoan religion. For Evans, the centre of Minoan religion was the Minoan Mother Goddess. It is not surprising, therefore, that he should interpret any evidence relating to Minoan religion in light of this basic premise. An interesting, and indeed not unimportant, case in point is the way in which he explained the evidence which he found upon his investigation of the peak sanctuary of Mt Iouktas ${ }^{39}$. This is all the more important because Evans at the same time discusses the evidence within a broader context, namely 'the Early Palace Cult of Knossos' and in fact 'its whole religious history' - in other words, within the broad framework of Minoan religion as such ${ }^{40}$.

Given the fact that Evans' interpretation, both in terms of the various points of detail and his general conclusions, has had a profound influence on the reconstruction of Minoan religion, one that persists until today, it may be useful to subject to review his interpretation of $\mathrm{Mt}$ Iouktas - and this at the same time also against the background of the latest excavations at the site, which have shed new light on the subject.

Evans, with the assistance of Mackenzie, carried out a preliminary excavation on Mt Iouktas in 1909. His reconstruction of the results is illuminating. He begins by referring to evidence available from similar contexts elsewhere, particularly from Petsopha at the eastern extremity of the island. No general conclusions are drawn from this site, however, except to observe that 'How late the religious associations of such votive stations as that of Petsofa went on in Crete itself is shown by the traditions that there clung to the legendary site of the "Tomb of Zeus», on Mount Jukatas..."41

After reviewing briefly these traditions, he refers to his excavation of 1909. Here he sets the tone for his reconstruction, not by beginning with the evidence itself, but by reference to topographical features, namely as seen from the Palace of Knossos : "The more northerly

39 Sir Arthur Evans, The Palace of Minos at Knossos, I, London, 1921, p. 151-163.

40 Ibid., p. 151.

41 Ibid., p. 153. 
summit, on which the peak sanctuary is situated, strikes the eye at Knossos itself. This makes possible the following comment :

'Here, it is natural to suppose, was the sacred peak of the Mother Goddess who presided over the Palace Sanctuary itself - a prototype, we may believe, of the lion-guarded pinnacle of the rock on which she appears on sealings of her central shrine, adored by a youthful male satellite - and within which her cult might naturally be associated with that of her divine son'42.

Only after this significant statement does Evans proceed to discuss the evidence unearthed by his excavation. Chief among the discoveries were the architectural installations, especially the ground plan of what he took to be the 'Sanctuary' itself (Fig. 1). This elicits the following conclusion :

'It was a little house of shelter and refection for the Goddess on her mountain top, a "Casa Santa», like that miraculously transported from Bethlehem to Loreto'43.

Evans then turns to the evidence from the small finds, namely such as afford a comparison with the "Dictaean Cave" - which leads him back to Cretan Zeus. This too is illuminating, for at this point Evans again appeals to evidence from Knossos :

1) 'a series of L.M. II signet impressions exhibiting the Minoan Mother Goddess, Lady of the Double Axe, standing on a rocky peak between the guardian lions and receiving the adoration of a votary perhaps himself a Priest King' (Fig. 2)44.

2) A gold-signet ring, obtained by Evans at Knossos on his first visit to the site in 1894 (Fig. 3$)^{45}$.

He chooses to comment on the latter first. Although this signet ring 'may be even taken to foreshadow the Tomb of Zeus'46, it does so only in a specific way. According to Evans, the principal scene consists of an epiphany, namely of 'a young male god', who is greeted - rather summoned down - by 'the Minoan Mother Goddess', in a mountainous

42 Ibid., p. 154 and 156. This is vintage Evans.

43 Ibid., p. 158.

44 Ibid., p. 159.

45 Loc. cit.

46 Loc. cit. 
landscape ${ }^{47}$. This god, 'her paramour or her actual son', was long known throughout the Eastern Mediterranean and Western Asia, and 'there is every probability the Cretan Zeus, the child of Rhea [of later tradition]... may be traced back to its earliest religious stratum'48.

After this casual nod to Cretan Zeus, Evans returns to 'the Great Mother', and sees as one of her functions that of mourning her permanently youthful but equally mortal consort, and thinks that it is easy to imagine such a scene of lamentation on another gold signet (Fig. 4) 49 . For Evans, there is no doubt that this mourning scene refers to the Minoan equivalent of the Near Eastern 'Adonis or Thamuz', but in a Minoan context he is depicted 'as a youthful warrior God, in other words the Cretan Zeus'50. Finally, Evans maintains that 'the rocky peak' was simply representative of 'the sanctity of the whole mountain', and that 'the summit was chosen as the object of cult' - namely, that of the Mother Goddess, and concludes his discussion by references to the Cave at Kamares and that on the limestone plateau of Skoteino, about three hours' journey east of the palace of Knossos ${ }^{51}$.

Just how valid is this interpretation? For one thing, it should be noted that in the notoriously difficult task of attempting to reconstruct a prehistoric religion without the aid of any text, and especially in the case of the 'Minoans', there is much room for highly varying views. Virtually any interpretation that pays due attention to the evidence and is characterised by controlled imagination may be regarded as legitimate. In view of this, Evans' interpretation of the peak sanctuary on Mt Iouktas should be regarded as entirely admissible, and as therefore providing significant insight into this highly complex problem.

On closer examination, however, it turns out that Evans' method in this discussion is fundamentally flawed, and this almost from the outset. While it may be entirely legitimate to draw on comparative material, this can only be valid if it is of a complementary nature - i.e., if it corroborates an interpretation which is deduced from the primary evidence. It cannot take the place of the primary evidence itself. But this is just what Evans has done. He actually begins correctly, by drawing attention to the tradition of the cult of Zeus at this particular site. Soon, however, he concentrates primarily on the Great Mother Goddess. In

47 Sir Arthur EVANS (n. 39), p. 160.

48 Loc. cit.

49 Sir Arthur Evans (n. 39), p. 161.

50 Ibid., p. 162.

51 Ibid., p. 162-163. 
other words, he switches horses in mid-stream. He never really discusses in any detail the cult of Cretan Zeus - apart from a number of isolated features. There appears to be a good reason for this. By 1909, when Evans had already conducted his preliminary excavations at the site, he had already developed his basic theories about Minoan religion and Minoan culture. For him, the Great Mother Goddess was the centrepiece of Minoan religion. It is scarcely surprising, therefore, that, in discussing the peak sanctuary of Mt Iouktas, the Great Mother Goddess should be seen as the primary object in the cult, and that Zeus accordingly should be relegated to only a secondary rôle.

It is important here to examine more closely just how Evans seeks to establish this relationship. As noted above, he brings the palace of Knossos into the discussion at the earliest possible moment. This affords the opportunity to appeal to the so-called 'Mother of the Mountains' seal impression (LM II) discovered in the palace ${ }^{52}$. In other words, Evans does not begin by appealing to the primary evidence at $\mathrm{Mt}$ Iouktas itself, and on the basis thereof proceed to make a link with the palace of Knossos. Rather, he begins from the premise of a presupposition - that of the primacy of the Great Mother Goddess ${ }^{53}$. Even if it could be proved by other means that the Great Mother Goddess was the chief deity in Minoan religion, it would still not be legitimate to assume that she was the primary object of worship at Mt Iouktas. This would only be valid if the evidence there pointed to a cult in which she was the primary object of veneration. It should be emphasised that neither at this

52 It should be noted that this impression is actually reconstructed from several separate fragments, thought to come from one single seal. On RUTKOWSKI's idiosyncratic interpretation of this seal impression, which is seen by many, as MATZ reminds us, as constituting the very essence of Minoan religion ('... Inbegriff der minoischen Religion' : F. MATZ, Göttererscheinung und Kultbild im minoischen Kreta, Wiesbaden, 1958, p. 14), see E.F. BLoEDow and C. BJÖRK, The Mallia Insect Pendant : A Study in Iconography and Minoan Religion, in SMEA, 27 (1989), p. 9-27. For his interpretation RUTKOwSKI later appealed, somewhat curiously, to the Odyssey, namely to the renewal of Minos' rule by conferring periodically with Zeus (B. RUTKowsKI [supra n. 2], p. 88). What he does not explain, however, is why, on the one hand, the Great Mother Goddess should be the deity to confer authority on the king, whereas, on the other, it is a male god who renews that authority.

53 And yet how many people have accepted EvANs' interpretation of Mt Iouktas without any reservations, especially when he claims that 'remains of an actual sanctuary of the Goddess here exist on the crest of the ridge', namely on the basis of nothing more than the presence of 'a votive stratum like that at Petsofa in the East of the Island' (Sir Arthur Evans, The Palace of Minos at Knossos, III, London, 1930, p. 468)! 
juncture nor indeed anywhere in the entire discussion of Mt Iouktas does Evans demonstrate that even a single piece of evidence which he excavated there points to the Great Mother Goddess. In fact, Evans' entire reconstruction of Mt Iouktas is based on what one should call extraneous evidence - i.e., evidence that was not found at the site ${ }^{54}$.

Two questions immediately arise. 1) Does this extraneous evidence actually make sense when, as it were, 'parachuted' onto Mt Iouktas ? 2) More particularly, does it agree with the evidence which Evans excavated at the site? There is now also a third question : How does it relate to the evidence from the most recent excavations?

Let us turn briefly to the three pieces of extraneous evidence on which Evans based his interpretation. Are his interpretations of these pieces acceptable in themselves? And if not, can they be adduced in connection with Mt Iouktas?

As for the 'Mother of the Mountains' seal impression, in a brief discussion elsewhere it has been shown that Evans' explanation of this piece is far from compelling 55 . Here the following considerations may be added. In another context, Evans discusses also another (fragmentary) seal impression - this one found in the Little Palace at Knossos (Fig. 5). He sees a specific link between this example and the 'Mother of the Mountains' impression :

'The guardian lions recall those on each side of the peak on which the Goddess stands, as seen on the signet-type of the Central Shrine $[=$ the 'Mother of the Mountains']'56.

As in the case of the seal impression from the Little Palace, here too the lions stand with their forepaws on what appears to be a heap of stones, which presumably forms the chief ground for the connection which Evans sees. In view of this, the seal impression from the Little Palace should also be connected with Mt Iouktas. Not so, however, according to Evans. As he sees it, the lions stand closer together, which 'makes it

54 As for the evidence from the site itself, none of the small finds have been published, except the ladle which Evans thought was inscribed with characters in Linear A, but this has now been contested (cf. infra n. 74). It is significant that EvANs illustrates material from, not his own excavations, but from the excavations at Petsopha (cf. Sir Arthur Evans [supra n. 1], p. 152, fig. 111).

55 See E.F. BLoEdow and C. BJöRK (supra n. 52).

56 Sir Arthur Evans, The Palace of Minos at Knossos, IV, 2, London, 1935, p. 610611. 
impossible to suppose that the Goddess herself stood between them'57. This enables Evans to postulate that the lions may have faced the spectator ${ }^{58}$, in which case they can be compared with the lions of the Lion Gate at Mycenae, which he regards (not surprisingly) as 'purely Minoan in inspiration and execution'59. This permits two further conclusions : 1) The lions positioned in this way may be regarded as 'a symbol of divine protection', forming 'a subject of sculptural or plastic adornment on an entrance portico, perhaps belonging to the sanctuary building in which it was found' [i.e., the Little Palace] ${ }^{60} .2$ ) This sculptural group 'stood quite free and open to the sky, like the statues and sculptural groups on classical cornices' 61 .

It is clear that in this seal impression as reconstructed the lions appear to be standing with their hind legs on some kind of a building complex, which could possibly be a free-standing structure. If that is the case, how is one to explain the so-called heap of stones (if it is in fact a heap of stones) between them ? If Evans' interpretation is to have any validity at all, this feature too should have some connection with the Little Palace. By the same logic, the feature between the lions in the 'Mother of the Mountains' impression should have some connection with the palace of Knossos - and not least since it was found in the palace and since the ground-line on which the lions stand with their hind legs in the reconstruction could also represent some kind of structure. And this is even more the case if the feature between the lions is not in fact a heap of stones, and therefore, by extrapolation, does not represent a mountain peak. On the other hand, if one insists that the feature between the lions in both seal impressions does in fact represent a heap of stones, indicating a mountain peak (if in this instance Mt Iouktas), the goddess should be guarding something in connection with the sanctuary there. One could therefore interpret these lions as guarding, not the sanctuary of the Mother Goddess, but the Tomb of Zeus, and the building to the left on the 'Mother of the Mountains' impression as signifying the buildings of the peak sanctuary itself ${ }^{62}$. For my part, since both seal impressions were found at Knossos, I should be inclined to see them as having

57 Ibid., 611 - scarcely adequate grounds for not seeing a connection with Mt Iouktas.

58 Note this interpretation in the reconstruction!

59 Sir Arthur EvaNs (n. 56), p. 614-615.

60 Ibid., p. 611-612.

61 Ibid., p. 612.

62 As we shall see below, this could be of crucial importance. 
reference to the structures in which they were found. As a matter of fact, Evans too regarded the scene as located in the palace of Knossos, for he took the building to the left as representing 'her actual Palace shrine'63. If the scene is therefore set in the palace of Knossos, the 'heap of stones' could represent any mountain (a Great Mother Goddess would not be restricted to a particular mountain, at least not a mountain as low as Mt Iouktas $[780 \mathrm{~m}])$. There are therefore no valid grounds for associating this heap of stones with Mt Iouktas. Consequently, one must reject Evans' interpretation, for in no way can it be accepted as having demonstrated the primacy of the cult of the Great Mother Goddess at the peak sanctuary on Mt Iouktas ${ }^{64}$.

The second piece to which Evans appeals, the gold ring from Knossos (Fig. 3) is even less convincing. Two points may be made in connection with it. In the first place, there are no grounds for identifying the female figure as a goddess. Evans, clearly, could not adduce any comparative evidence to demonstrate that a goddess is actually 'bringing down the warrior youth, whether her paramour or her actual son'. All he could do, it seems, was to draw attention to 'Babylonian analogies' which illustrate "hands raised in an attitude of... prayer or incantation' 65. This is not a gesture or activity which one normally associates with a deity - rather with a human being. Consequently, Nilsson's interpretation seems to be preferable, that this scene 'shows a woman worshipping a god who hovers in the air'66. The sole possibly direct connection between this ring and a peak sanctuary is comprised of the features to the left of the scene, which Evans explains as 'rocks and vegetation indicative of a mountainous locality' 67 . This strikes one as very tenuous evidence for a mountainous terrain. Vegetation there seems to be indeed. But whether the other features are to be taken as

63 In passing, it may be worth pointing out that the Mother of the Mountains' sealing is not without problems. Having been discovered in the 'final Mycenaean destruction horizon', and therefore 'probably dating from the thirteenth century B.C'., 'we cannot be sure whether it is a Minoan heirloom, a ring made in pure Minoan tradition or a genuine Mycenaean ring' (E. HALLAGER, The Master Impression, Göteborg, 1985 [SIMA, 69], p. 29 n. 145).

64 Thus Evans (supra n. 56), p. 607.

65 Sir Arthur EvaNs (supra n. 39), p. 160.

66 M.P. Nilsson (supra n. 1), p. 256. See also A.W. Persson (supra n. 29), p. 61 and 90, and the remarks by MATZ (F. MATZ [supra n. 52], p. 11-12 and 15), where he also draws upon comparative material. Both take the female figure to be an adorant.

67 Sir Arthur Evans (supra n. 39), p. 160. 
indicating rocks, is highly dubious. And even if they were meant to indicate rocks, this would still be far from requiring one to conclude that they indicate mountainous terrain, especially since there are rocks just about everywhere, even at low altitudes, throughout the island. And what of the combination of rocks and vegetation? If Rutkowski, for instance, is correct in maintaining that peak sanctuaries were almost invariably located on bleak mountain tops, denuded of virtually all vegetation ${ }^{68}$, the connection would appear to be even more dubious. There is in fact nothing to prevent one from taking all the features on the extreme left of the ring as indicating vegetation, i.e., ordinary vegetation which does not have any connection with mountain peaks. Furthermore, the architecture which is portrayed, which is certainly to be regarded as condensed, depicts a fairly complex series of structures, such as one would associate with a place that was frequented much more often than one was likely to find upon climbing up to a peak sanctuary. It would appear to fit into a palace context much more suitably than into a barren isolated mountain top.

Much the same applies to Evans' third piece of extraneous evidence the gold ring from Mycenae (Fig. 4). While this may indeed represent a mourning scene, there is nothing in it which requires one to see in the central figure a goddess (the Goddess) ${ }^{69}$. Nor is it likely that the Goddess would appear twice in the same scene ${ }^{70}$. And why the Goddess should require or obtain 'refection from the fruit of a tree' in such (or any) circumstances too is not explained by Evans. How could a deity who was so weak be of any help to humans? And what grounds are there for associating this scene with 'the Cretan Zeus'? For Evans, this emerges from the very nature of the scene, but this is not at all compelling. It would be preferable to view this example in conjunction with

68 '... the exposed mountain tops, which were subjected to strong winds, were not places that favoured the growth of trees. The strong gusts of wind, and gales coming from the west and north, not only were physically destructive of vegetation, but also caused violent changes of temperature that were also harmful to it' (B. RUTKOWSKI [supra n. 1], p. 155). RUTKOwSKI does allow for some exceptions, but I do not recall seeing any significant vegetation at the peak sanctuaries which I visited.

69 EvANS actually accepts that it could be 'the Goddess or her attendant'. If the latter, however, it could scarcely be construed as depicting the Goddess mourning her 'consort, son or paramour'.

70 EvaNs sees the female figure in the centre as 'perhaps the Goddess repeated' (Sir Arthur EvaNs [supra n. 1], p. 161). Cf. the reference to this piece by MaTZ, who sees it as forming part of a series depicting a scene of epiphany (F. MATZ [supra n. 52], p. 12 and 15). 
similar scenes, and, with Persson, see this series as a picture of 'the season of winter and the coming of spring 71 . In that case, the mourners, alias, worshippers, may indeed all be humans, possibly priestesses and priests, and the object of their veneration may be the realm of nature, or in fact a goddess (see below) just as much as a god. One will therefore require evidence of a different kind to demonstrate that the Mother Goddess is portrayed on this ring. Although he thought it incidental, Evans maintained that "The mountainous locality in which the scene is placed supplies an additional warrant for identifying the site with the peak sanctuary of Juktas'72. Unfortunately, Evans does not specify just which features in the scene he thinks indicate a 'mountainous locality'. Perhaps he had in mind the feature on which the figures are standing, which looks as if it consists of stones. These 'stones', however, are arranged so regularly that they give much more the impression of being man-made than any natural mountainous terrain.

Thus Evans' case for associating these three pieces of evidence with the peak sanctuary on Mt Iouktas simply evaporates under closer scrutiny. None of them can be said to have the remotest connection with such a place, and therefore do not provide any evidence whatsoever that the cult on Mt Iouktas was centered around the Great Mother Goddess and this, despite the fact that during the last phase of the peak sanctuary there appears to have been a closer connection between the palace of Knossos and Mt Iouktas.

\section{The Cult of Zeus in Light of New Evidence from Mt Iouktas}

It is clearly time to turn to the primary evidence - the evidence from the site itself. Of fundamental importance here are now the latest excavations, which have been conducted by Mrs. Alexandra Karetsou between 1974 and 1986, and which have brought to light important new information ${ }^{73}$.

71 A.W. PERsson (supra n. 29), p. 32-46, 88-89. He also notes that 'When the vegetational god... is buried, the Universal Goddess of Fertility disappears over the sea, only to return when vegetation is reborn' (ibid., p. 99).

Sir Arthur Evans (supra n. 1), p. 162.

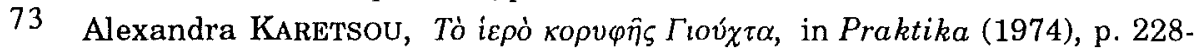
239; (1975), p. 330-342; (1976), p. 408-418; (1977), p. 419-420; (1978), p. 232258; (1979), p. 280-281; (1980), p. 337-353; (1981), p. 405-408; EAD., in Ergon (1974), p. 112-114; (1975), p. 176-178; (1976), p. 184-188; (1977), p. 181-185; (1978), p. 62-65; (1979), p. 29-30; (1980), p. 337-353; (1981), p. 405-408; EAD., The peak sanctuary of Mt. Juktas, in R. HäGG and N. MARINATOS (eds.), 
What does the evidence from the site in fact tell us ${ }^{74}$ ? The evidence consists of two kinds : architectural features and small finds. Before looking at both of these, we may note that according to the excavator there appear to be two specific phases into which use of the sanctuary falls. In the first of these, in the Old Palace period (i.e., beginning in MM IA, 'a little before the establishment of the first palaces'), it was 'the open-air sanctuary of the Knossos area', whereas in the second, i.e., beginning in MM III, 'the connection of the sanctuary with the Palace of Knossos becomes clearer' 75 . The reasons for the latter were : 1) 'the architectural remains... are monumental', and 2) 'the character and quality of the finds have a palatial character ${ }^{76}$. These factors, incidentally, place the peak sanctuary on Mt Iouktas in a category by itself.

\section{The Architecture}

a) The Terraces : Doubtless one of the most important results of the latest excavations is that "The area which Arthur Evans called the priest's house [his 'Casa Santa'] has proved to be the main part of the open-air sanctuary' (Fig. 6)77. This consists of two stepped terraces, designated as Terrace I and Terrace II 78 .

Along the east side of Terrace II, five rooms were uncovered, arranged in a row from south to north. Although the exterior (eastern) wall of the rooms measures a little over $24.50 \mathrm{~m}$, and may therefore give the impression of a certain monumentality, the rooms themselves, i.e., the interiors, are very small. The largest, for instance, Room II, measures ca. $2.30 \times 1.30 \mathrm{~m}$, while the smallest, Room V, measures only ca. $1.50 \times 1.30 \mathrm{~m}$. Nor does there appear to

Sanctuaries and Cults in the Aegean Bronze Age. Proceedings of the First International Symposium at the Swedish Institute in Athens, 12-13 May, 1980, Stockholm, 1981, p. 137-153.

74 As already noted above, Evans treats the evidence which he unearthed in summary fashion. The only specific item which appears to have been published is the ladle which he thought was inscribed with characters in Linear A (cf. Alexandra KARETSOU, The peak sanctuary of Mt. Juktas [supra n. 73], p. 146 n. 25). The evidence from the latest excavations therefore assumes great importance.

75 Alexandra KARETSOU, ibid., p. 145, cf. p. 151. The sanctuary continued to be used until LM III A-B.

76 Ibid., p. 145.

77 Ibid., p. 138.

78 A fourth terrace also came to light (cf. Alexandra KARETSoU, in Praktika [1981], p. 408). For Terrace III, cf. EAD. (supra n. 74), p. 145, and EAD., in Praktika (1980), p. 337-343; (1981), p. 405-408. 
have been any entrance to these rooms from the exterior walls (south, east, north). The purpose of these rooms too seems to be somewhat unclear. The excavator thinks that they played 'an auxiliary part in the worship at the shrine' - deduced from the fact that many finds turned up in these rooms ${ }^{79}$.

Along the (eastern) exterior wall of these rooms, at a height of $0.45 \mathrm{~m}$ above the level of Terrace III, a long narrow bench was discovered. Here, i.e., just below this bench, hundreds of offerings were found ${ }^{80}$.

b) The Altar : A long stepped altar was identified on the west side of Terraces I and II. Its preserved length measured $4.70 \mathrm{~m}$ and its preserved height $0.50 \mathrm{~m}$. It was built on top of deep fissures in the bedrock, and 'constitutes the crown of the Terraces, and marks the end of the ascending ceremonial way'81.

c) Offering Table : An offering table of greenish stone with white veining was discovered 'built into the altar'. It measured $0.56 \times 0.37$ $x 0.08 \mathrm{~m}$, and dates from 'the first phase of the sanctuary' 82 .

d) The Chasm : Between Terraces I and II 'a deep natural chasm' was discovered. It has been excavated to a depth of $10.50 \mathrm{~m}$, without the bottom having been reached. This chasm was found by following one of the natural fissures in the bedrock 83 .

\section{The Finds}

Thanks to their quantity, character and diversity, the small finds from the peak sanctuary on Mt Iouktas, especially from the latest excavations, assume particular importance. Here it will suffice to draw attention to only the most diagnostic.

1) Kernoi

a) A poros kernos, measuring $1.85 \mathrm{~m}$ wide and $0.40 \mathrm{~m}$ high, was found close to the altar. It has a single large cavity in the middle, but many small circular cavities at each end, arranged in straight rows 84 .

b) An alabaster kernos, forming an essentially triangular shape by the three circular, deep, contiguous depressions. It was found in Room I85.

c) A fragmentary kernos made of stone, found at the SE outer corner of Room I. Three circular cavities are preserved and a section of the

79 Alexandra KARETSOU (supra n. 74), p. 147.

80 Ibid., p. 145.

81 Ibid., p. 138 and 141, cf. p. 146, fig. 11.

82 Ibid., p. 145.

83 Ibid., p. 141. For further discussion of this feature, see below.

84 Cf. EAD., in Praktika (1974), pl. 173ß; EAD. (supra n. 71), p. 148, fig. 13.

85 EAD. (supra n. 74), p. 150, fig. 23. 
fourth ${ }^{86}$. According to the excavator, this kernos measures ' $0.034 \mathrm{~m}$ long, $0.019 \mathrm{~m}$ wide and $0.012 \mathrm{~m}$ high' 87 , but these figures appear to be problematic.

2) Offering Tables

a) An offering table made of greenish stone with white veining was discovered built into the altar. It measured $1.56 \mathrm{~m}$ long, $0.37 \mathrm{~m}$ wide and $0.08 \mathrm{~m} \mathrm{high} 88$. (Cf. 1) c) above.)

b) A small rectangular offering table made of white-veined alabaster, found in Room V. It also had right-angled notches in the middle of each of the four sides. It measured $0.07 \times 0.06 \times 0.04 \mathrm{~m}^{89}$.

c) A section of an offering table made of obsidian 90 .

d) An offering table made of black stone, of outstanding quality, found in the area of the altar. It was inscribed with two lines in Linear $A^{91}$.

e) A round stone offering table, found in the circuit wall. It was decorated with incised leaf motifs, and dates to $\mathrm{LM}^{92}$.

f) A considerable number of other offering tables were found, some round, some rectangular, of varying sizes ${ }^{93}$.

\section{3) Figurines}

A) Humans

a) A lead figurine of a male worshipper, found in Room III and $0.044 \mathrm{~m}$ high 94 .

b) Of special interest is a bronze figure of a male adorant, $0.089 \mathrm{~m}$ high, and in an excellent state of preservation, although covered with a dark green patina95. The excavator draws attention to the fact that the figure has his left foot forward, that his body is articulated by a tension and clean lines which one does not meet again until the

86 Cf. EAD., in Praktika (1980), pl. 207a.

87 Cf. EAD., in Praktika (1980), p. 342.

88 Ean. (supra n. 74), p. 145.

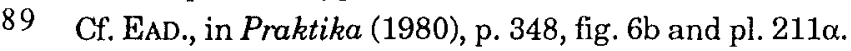

90 Cf. EAD., in Praktika (1980), pl. 2078.

91 EAD. (supra n. 74), p. 146. At least nine votive offerings with Linear A signs have been found thus far.

92 Cf. EAD., in Praktika (1979), pl. 162ß.

93 Cf. EAD., in Praktika (1980), p. 348; (1981), p. 408; EAD. (supra n. 74), p. 146.

94 Cf. EAD., in Praktika (1975), pl. 265\%; EAD. (supra n. 74), p. 150, fig. 25. About 300 clay figurines of adorants have already been discovered (ibid., p. 147).

95 Cf. EAD., in Praktika (1980), pl. 2073-\%. 
Archaic kouroi. In addition, the round face, the engraved eyes and the round head are features rarely found in Minoan figurines 96.

c) A series of S-shaped clay votive objects 97 . One suggestion has it that they might be embryos, another that they represent women in the position of giving birth ${ }^{98}$.

d) Otherwise, a large number of clay figurines, whole or only parts of the human anatomy, of both sexes, but with males clearly in the majority 99 .

B) Animals

A large number of animal figurines was found, of varying sizes. Most of these are unidentifiable as to species. Some which can be identified include bulls, pigs, sheep and goats ${ }^{100}$.

C) Other

Also a large number of clay models of bulls' heads, snakes and birds was found ${ }^{101}$, as well as an embossed bronze sheet in the shape of a bird ${ }^{102}$.

4) Double Axes

a) Alongside the poros kernos found near the altar, 'a treasure of bronze double axes' was discovered ${ }^{103}$. Thirty-two of these are small (0.12-0.09 $\mathrm{m}$ long), but two are large $(0.24 \mathrm{~m}$ long) They have been dated to the Old Palace stratum ${ }^{104}$.

b) A bronze double axe, $0.07 \mathrm{~m}$ long, was found in Room III in $1980^{105}$.

5) Miscellaneous

A series of other significant items was found, indicating further variety. The most important of these include :

96 EAD., in Praktika (1980), p. 342.

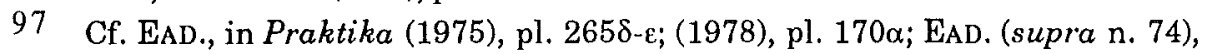
p. 149, fig. 16.

98 EAD. (supra n. 74), p. 146.

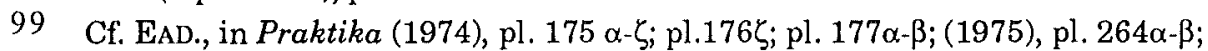

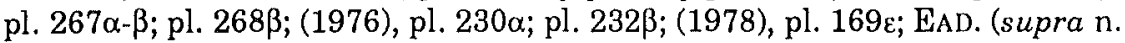
74), p. 149, fig. 17-20.

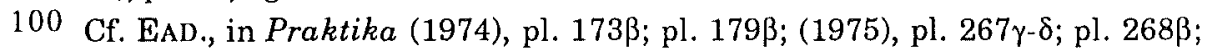
(1976), pl. 230ß- $\gamma$; EAD. (supra n. 74), p. 150, fig. 21-22.

101 Cf. EAD., in Praktika (1974), pl. 1768; (1978), pl. 170

102 Cf. EAD., in Praktika (1976), pl. 230ל; EAD. (supra n. 74) 151, fig. 26.

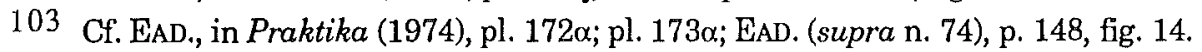

104 EAD. (supra n. 74), p. 146.

105 Cf. EAD., in Praktika (1980), p. 345. 
a) A highly interesting clay seal impression found in Room I, depicting a bull's head with a star symbol between the horns ${ }^{106}$.

b) An alabaster cup, $0.025 \mathrm{~m}$ high and $0.042 \mathrm{~m}$ in diameter, also found in Room I. It is inscribed with a band of Linear A writing all around the wavy rim, in very clear characters ${ }^{107}$.

c) A gold amulet, thought to be apotropaic, $0.013 \mathrm{~m}$ in diameter. It shows a scorpion, a snake and an insect ${ }^{108}$.

d) A number of excellent seal stones, from different parts of the site ${ }^{109}$.

e) Large quantities of pottery, dating from MM I A to LM III A-B, and some of even LM III $\mathrm{C}^{110}$.

f) There were also numerous stone vessels ${ }^{111}$.

We may now pose the question which has long been in the forefront of our minds. Which deity was the object of veneration at the peak sanctuary on Mt Iouktas ? Or was there perhaps more than one deity? One might be inclined to interject that, since there are strong grounds for concluding that there was a close link between this sanctuary and the palace of Knossos, one may regard the same deity (or deities) as being worshipped in both places. By the same token, should one not conclude, in a later age that, because it too was in Attica and because the inhabitants of Attica were Ionians, the temple and cult at Sounion should also have been associated with Athena, just as was the Parthenon on the Acropolis in Athens, rather than with Poseidon? Each cult place must be studied first and foremost in light of the evidence from the site itself.

Just what does the large body of evidence from Mt Iouktas now tell us about the cult and the deity (or deities) connected with it? Firstly, we may make several general observations. To begin with, despite the quantity, character and diversity of the evidence, neither the nature of the cult nor the deity worshipped there become immediately clear. Secondly, the evidence cannot be said to point specifically to a female

106 Cf. EAD. (supra n. 74), p. 150, fig. 24.

107 EAD., in Praktika (1977), p. 419-420, cf. EAD. (supra n. 74), p. 147.

108 Cf. EAD, in Praktika (1977), pl. 422א, cf. EAD. (supra n. 74), p. 147.

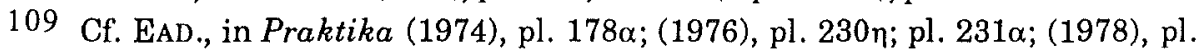
$169 \alpha-\delta$.

110 Cf. EAD., in Praktika (1974), pl. 179\%; (1975), p. 333, fig. 1, p. 337, fig. 5, p. 338,

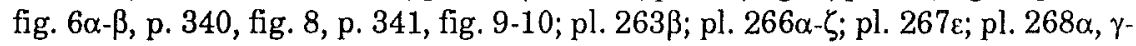

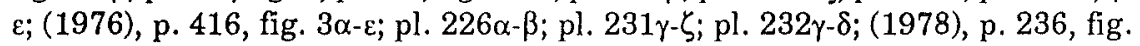
4 ; p. 237, fig. 5; p. 240 , fig. 7 ; p. 248, fig. 11 ; p. 250, fig. 12; p. 253, fig. 13; p. 254,

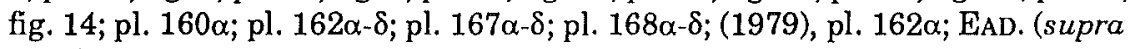
n. 74), p. 144, fig. 8-9.

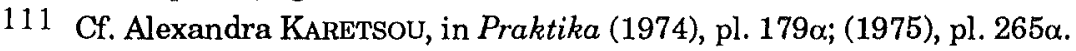


deity, much less to a Great Mother Goddess - although it must be admitted that to date no generally accepted criteria have been advanced whereby to identify either of the above. At the same time, however, the excavator has pointed out that in the finds the male component is unquestionably the dominant factor. Not a single striking female representation has come to light, namely in what is now a large body of evidence.

With these general observations as a background, we may proceed to examine some of the evidence in greater detail. One of the most striking discoveries at the site was unquestionably the large chasm. This 'deep natural chasm' is situated between Terraces I and II, with its entrance adjacent to the altar, i.e., 'the altar is built virtually on the lip of the chasm' (Fig. 6 and 7) ${ }^{112}$. It accordingly occupies a central location on the site. This being the case, it should figure prominently in any interpretation of the evidence. Given the long tradition of the site as the 'tomb of Zeus', what place could be more suitable as the burial spot of Cretan Zeus, who dies annually and is reborn annually? This becomes all the more plausible, given the famous nature of the myth ${ }^{113}$, and the enduring character of the tradition associated with it ${ }^{114}$.

Is there anything within the finds which might substantiate the primacy of Cretan Zeus at this site? An equally remarkable discovery was the treasure of double axes ${ }^{115}$. These axes were found, as noted above, near the altar. The two large ones, with shaft holes, call for particular attention. Of what relevance might they be ? Here it may be appropriate to draw attention to a festival of Zeus in Athens - the Dipolieia (Zeus Polieus = Zeus, Protector of the City). Now Erika Simon has aptly noted that this was 'the oldest and strangest of all Athenian festivals'116. One of the principal elements in this festival was the bouphonia, the slaying of a bull or ox. Simon traces this notion back all the way to Neolithic times. At the same time, however, there are good reasons for concluding that the form in which it was observed in Athens stems directly from Minoan-Mycenaean traditions.

Another essential feature of the festival was an altar, or (as Porphyry put it) a bronze table. Simon pertinently notices that precisely

112 Alexandra KARETSOU (supra n. 74), p. 138 and 141.

113 M.P. NiLsson (supra n. 1), p. 553-554.

114 Alexandra KARETSOU (supra n. 74), p. 137.

115 Another bronze double axe was found in Room III.

116 Erika Simon, Festivals of Attica. An Archaeological Commentary, Madison, Wis., 1983, p. 8. 
such a table is 'a common-place in representations of bull-offerings in Minoan and Mycenaean art', as Sakellarakis has demonstrated in a discussion of a vaulted tomb at Arkhanes, situated on the east foot of $\mathrm{Mt}$ Iouktas ${ }^{117}$. Simon even goes so far as to suggest that the table-like structure on the Athenian Acropolis may indeed have been 'a relic of the Mycenaean age'118.

During the celebration of the festival, grain or cakes (or both) were placed on the altar-table, and the bulls or oxen driven around it. The bull/ox which ate from these victuals became ear-marked as the victim for sacrifice, and was slain by a double axe - the pelekus. Like the table, this too may be regarded as a relic of the Mycenaean period. The axe was wielded by the bouphonos.

There can be little doubt that this cult at Athens goes back, in essentially this form, to Minoan tradition. It is remarkable that at Athens it should have retained unmistakable features of, not mainland Hellenic, but of Cretan Zeus. How much more firmly established must the cult have been in Crete!

The slaying of the bull in the original cult presumably symbolised the dying of Zeus. Is it possible that the offering table of greenish stone with white veining $(1.5 \times 0.37 \times 0.08 \mathrm{~m})$ and built into the altar may have served as the altar-table on which the victuals were placed, and the altar itself the piece of furniture on which the bull was sacrificed ${ }^{119}$ ? And may the two large bronze double axes have been used to slay the bull ${ }^{120}$ ?

117 J. SaKellaraKis, Das Kuppelgrab A von Archanes und das kretischmykenische Tieropferrituel, in Prähistorische Zeitschrift, 45 (1970), p. 166198. Sakellarakis elsewhere points out the close relationship between Arkhanes and Mt Iouktas (J. SaKellarakis, Minoan Cemeteries at Arkhanes, in Archaeology, 20 [1967], p. 281), cf. Alexandra KARETSOU (supra n. 74), p. 151.

118 Erika SimON (supra n. 116), p. 9.

119 The prominence of also the bull at the site ought to give strength to this plausibility. Cf., in particular, the clay sealing showing a bull's head with a star symbol between the horns.

120 Referring to double axes, BURKERT maintains that most of those which have been discovered are 'votive gifts never intended for practical use : they are too small or too large, too thin or too ornamentally formed, and also they are made of lead, of silver, and of gold' (W. BuRKerT [supra n. 1], p. 38). By contrast, the large bronze axes from Mt Iouktas, measuring $0.24 \mathrm{~m}$ long, should have been ideally suited for slaying a bull. At the same time, the small double axes may be taken as reinforcing the purpose of the large ones. As BuRKERT reminds us, 'The double axe is a symbol of power, the power to kill' (loc. cit.). 
One is inclined to see this as a distinct possibility. The various kernoi found at the site could also fit into the practising of this cult.

If then the evidence points in any direction at all, it is towards the cult of Cretan Zeus. This is also the way in which the excavator appears inclined to see it. As Karetsou puts it, 'the deep chasm... which probably represents an entrance to the underworld, justifies both the myth and the recent excavations'121.

But what of the question whether any other deities may also have been associated with the peak sanctuary on Mt Iouktas, especially a Great Mother Goddess ? While Karetsou is inclined to accept a significant emphasis on Cretan Zeus here, she considered this essentially within a traditional perspective. Thus she accepts Evans' 'valuable conclusion that Juktas was the holy mountain of Knossos', as well as his interpretation of 'the goddess who is worshipped in the peak sanctuaries, the 'Mountain Mother' (Oreia Meter) and her connection with the young male god who is sometimes called Velchanos and sometimes Hyakinthos. It seems that in Crete this place may be occupied by the newborn child who is there called Dias or Zeus', a notion one can also find in 'Dionysiac worship'122. And as she concludes her study, 'This short description of the Minoan goddess and her young male companion is intended to show the parallel adoration of these two divinities' ${ }^{123}$.

I, for my part, do not see anything in the evidence which points specifically to a 'Minoan goddess' - 'Mother of the Mountains' or otherwise. Nor, notably, does Karetsou isolate any evidence to this effect. Until this has been done, I would argue that we may regard the cult to be that of Cretan Zeus - and if not so exclusively, certainly primarily ${ }^{124}$.

121 Alexandra KARETsou (supra n. 74), p. 153.

122 Ibid., 151 and 153.

123 Ibid., 153.

124 Here it may be appropriate to draw attention again to the point made above, namely that if one wishes to concede that the so-called 'Mother of the Mountains' seal impression is in fact in some way related to the peak sanctuary on Mt Iouktas, it would be better to see her as guarding, not the peak sanctuary, but the 'tomb of Zeus' (to be envisaged as erected over the entrance to the chasm), and the structure to the left of the scene as the buildings of the sanctuary situated on the various Terraces. (It may be noted in passing that Evans himself regarded the structure to the left of the scene as representing 'her actual Palace shrine' (Sir Arthur Evans, The Palace of Minos at Knossos, IV, 2 [1945], p. 607). Such a dichotomy, however, reduces further any direct connection between a Great Mother Goddess and the peak sanctuary on Mt Iouktas.) Here it may also be valid to point out that two of the great authorities on Minoan religion, NILSSON and MATZ, regarded the male 


\section{The Cult of Zeus in Broader Perspective}

If one now accepts that there was such a specific cult of Cretan Zeus at this peak sanctuary, which, by reason of the evidence, becomes a highly important cult centre, should one perhaps begin to take a fresh look at the evidence from other sites too - not least in view of the degree to which the cult of Cretan Zeus was later so widespread in the island?

As the eminent Wilamowitz once noted, 'Zeus it is whom the Cretans venerate in just about every town and village'125. The principal testimony to this cult in historic times is the so-called Hymn of Palaikastro or the Hymn of the Kouretes in Honour of Zeus Diktaios, preserved in an inscription found at the beginning of this century on the site of the Temple of Zeus Diktaios at Palaikastro. It dates from $c a \mathrm{AD} 200$, although it is based on a much earlier text of $c a$ the third century $\mathrm{BC}^{126}$; in fact it may be as early as the fifth century $\mathrm{BC}^{127}$. One may regard as of no mean significance the discovery, during the most recent excavations at precisely Palaikastro, of 'the torso and arms of a superb ivory statuette with gold foil adhering... of a male figure in the same pose as the terracotta statuettes from nearby Petsopha'. The excavators think that this statuette 'may represent the Minoan youthful God'128. Although it dates from a LM IB context, the correspondence with the Petsopha statuettes, which are earlier, may allow us to see continuity here, and therefore permit one to suggest an even earlier date for the cult.

figure in this seal impression as a 'votary' or 'adorant' ('ein Beter') (cf. M.P. NILsson [supra n. 1], p. 352-353; F. MATZ, Kreta, Mykene, Troja. Die minoische und die homerische Welt, Darmstadt, 1957, p. 80, and, in particular, ID. [supra n. 52], p. 14-15.). If this is accepted, and it seems to be much preferable, Evans' idea of the 'Mother Goddess' being 'adored by a youthful male satellite... her divine son' must be abandoned, since one can scarcely conceive of one deity 'worshipping' another deity. This is even more the case since Evans later himself regarded the male figure as a 'worshipper' (Sir Arthur EvaNs, ibid., p. 607).

125 U. von Wilamowitz-MOELlENDORFF, Griechische Verskunst, Berlin, 1921, p. 501.

126 It was published initially by R.C. BOSANQUET, The Palaikastro Hymn of the Kouretes, in $A B S A, 15$ (1908-1909), p. 339-356.

127 U. von WILAMOWITZ-MOELLENDORFF (supra n. 125), p. 502.

128 J.A. MacGillivray, in $A J A, 92$ (1988), p. 242, cf. H. SacketT and S. MACGillivraY, Boyhood of a God, in Archaeology, 42 (1989), p. 26-31. 
Coins from different centres of Crete also attest the cult. Such coins depict a youth ${ }^{129}$, seated in the branches of a tree. This youth is designated as $F \dot{\varepsilon} \lambda \chi \alpha v o \zeta$. West has suggested that 'Welchanos [a strange and enigmatic term]... may have been the original "Minoan" name of the Cretan Zeus' ${ }^{\prime 30}$. If this is correct, the references to this term in historical times must be regarded as highly important, given their distribution throughout large parts of Crete. Thus, in addition to the prominence of Welchanos in the Hymn of Palaikastro, there was at Lyttos and Gortyn, and possibly also at Knossos, a festival called the Welchania, which, took place, appropriately, in spring. Moreover, there was at Knossos and Gortyn a month called Welchanos. There are also the 'Belchanioi' at Lyttos' ${ }^{131}$. And also in historical times a temple of Zeus Welchanos was built on the ruins of the palace at Hagia Triada ${ }^{132}$. We have too the well-attested legend of the birth of Cretan Zeus in the Cave on Mt Dicte at the western edge of the Lasithi Plain 133 .

The fact that it is now possible to argue for a cult of Cretan Zeus in Bronze Age Crete has significant implications for the study of Minoan religion in general. It may, for instance, require us to modify somewhat the view that it was not until the 'end of the Minoan Age' that there is 'the tendency to raise him [a male deity] to a superior status'134. Willetts, however, proceeding from the premise that the social importance of women', combined with 'the matrilineal rights of inheritance and descent', signifying an inferior status for men, produces 'the dominance of the goddess', and therefore also the inferiority of any male deity, accepted Fraser's conclusions about 'the connnexion between the youthful god and agrarian magic', namely that 'This god must die so that the crops may live'. In this scheme of things, 'The element of continuity in this vegetation cycle is represented by the

129 There is a correspondence here between the numismatic and the epigraphic evidence. In the Hymn, Zeus' youthful aspect is emphasised by the invocation at the beginning of the poem and by the repeated refrain, «Io, Greatest Kouros".

130 M.L. WEST, The Dictaean Hymn to the Kouros, in JHS, 85 (1965), p. 155 n. 9; cf. F. SCHACHERMEYR, Die minoische Kultur des alten Kreata, Stuttgart, 1964, p. 149.

131 F. SCHACHERMEYR (supra n. 130), p. 149.

132 M.P. NiLsson (supra n. 1), p. 550; F. SCHACHERMEYR (supra n. 130), p. 149.

133 Cf. A.B. Cook, Zeus, II, Part ii, Cambridge, 1925, p. 925-929; M.P. Nilsson (supra n. 1), p. 61-64, 458-460; and E.F. BLOEDOW and C. BJöRK (supra n. 52).

134 R.F. WilleTTS, Cretan Cults and Festivals, London, 1962, p. 79, cf. ID., The Civilization of Ancient Crete, London, 1977, p. 125. 
goddess, who also maintains the continuity of human life. The element of discontinuity, of growth, decay and renewal is a god'135. This of course depends on the presupposition of direct acceptance by the Minoans of details from the Near East and Western Asia, a view championed by Evans, but against which Nilsson cautions, pointing out that it does not take into account 'the independence of Minoan genius'136. But the only explanation offered for the male god in this rôle is that 'he personifies the seed and, because he shares in its mortality, he is a dying god ${ }^{137}$.

This of course reflects the commonly held view on Minoan religion, but it may be something of an oversimplification. There is no doubt that this commonly held interpretation appears to be compelling. Accordingly, Minoan religion was dominated by the female element, there being very little evidence to suggest any significant rôle played by male deities. As Nilsson pointed out in his day, 'except for the Master of Animals male gods are surprisingly rare, and even he appears on the whole less frequently than the corresponding female deity... Other representations, at least the indisputable ones may be counted on the fingers of one hand'138. One therefore saw this evidence in terms of 'the cult and myths of the Magna Mater conceived as the Great Mother of Nature, at whose side stands a mortal consort, her son or paramour, who dies and is lamented but revives again, and whose epiphany is celebrated in joyous festivals. A similar pair are the Semitic gods, Ishtar and Tammuz'139. And, based on the evidence from the Near East and Western Asia, the male component was seen as strictly inferior and subordinate, a view which the Cretan evidence seemed to substantiate.

It is worth pointing out, however, that Willetts elsewhere cites with approval Nilsson's interpretation of the cult of Ariadne ${ }^{140}$. Nilsson notes that the 'common opinion' about Ariadne is that she was 'an old goddess of Nature', and himself concludes that her cult is probably 'of Minoan origin'. Nilsson takes as his point of departure her cult on the island of Naxos, where, according to tradition, Theseus treacherously abandoned her after she had rescued him from the Labyrinth at Knossos. After surveying the cult of Ariadne in various places

135 R.F. WILLETTS, Cretan Cults and Festivals, London, 1962, p. 80.

136 Sir Arthur EvaNs (supra n. 53), p. 468, cf. M.P. Nilsson (supra n. 1), p. 404.

137 R.F. WILLETTS (supra n. 135), p. 80.

138 M.P. Nilsson (supra n. 1), p. 400. Or as BURKER'T puts it, 'The status of male deities in the iconography is precarious' (W. BURKERT [supra n. 1], p. 42).

139 M.P. Nilsson (supra n. 1), p. 401.

140 R.F. WILlETTS, The Civilization of Ancient Crete, London, 1977, p. 121-122. 
throughout the Greek world in historical times, he notes that in these her death is the salient feature', and that 'No other heroine suffered death in so many ways as Ariadne, and these different versions can only be explained as originating in a cult in which her death was celebrated'. But her cult at Naxos was peculiar, and important. In fact there were two festivals, corresponding to two Ariadnes : 'an older Ariadne, the wife of Dionysus, and a younger Ariadne, whom Theseus had won and abandoned, and who had died on Naxos'. The one festival was celebrated 'in honour of the older Ariadne with joy and merrymaking, the other in honour of the younger Ariadne, comprising sacrifices mingled with sorrow and gloom'. There is no doubt for Nilsson that 'the two festivals belong to the same goddess' 141 .

According to Nilsson, these festivals are reminiscent of 'a type of vegetation-festival', i.e., a type that was 'well known from the Oriental religions but foreign to the true Greek religion'. In such a vegetationfestival, 'The death of the god of vegetation is celebrated with sorrow and lamentations; his resurrection with joy and exultation'. But, as he also notes, "The death of such a goddess is unique', but he is prepared to accept that 'the idea of the death of vegetation may be applied not only to the god but also to the goddess of fertility'. This is all the more understandable in light of the later Greek cult of Demeter and Kore, in which the goddess is now in the 'weaker' position. Consequently, there need not be any obstacle to the idea that 'the goddess of fertility also dies', or that her death was celebrated annually, because she dies every year. And not least important is Nilsson's conclusion that, because this idea is 'unGreek' and 'does not occur in Asia in this form', it 'must therefore be considered as an original product of Minoan religious genius'142.

If Nilsson's interpretation is accepted, we would appear to have two deities in Minoan religion who were associated with the vegetation cycle in nature, i.e., deities who die and are reborn - a goddess and a god (the latter, Welchanos, later Zeus). Just how old the cult associated with the goddess was is difficult to say, but given the dominance of the female

141 M.P. NiLsson (supra n. 1), p. 523-525.

142 Ibid., 527-528. It may also be noted that, on a bead-seal from Thisbe, according to Evans, "the Minoan Mother Goddess is herself seen rising from the earth like Gaia and Persephone, and as in their case, holding poppy capsules that stand as a symbol of reproductive power' (Sir Arthur Evans [supra n. 53], p. 468). Moreover, according to tradition (the Homeric Hymn to Demeter), Demeter arrived in Greece from Crete, and in historical times 'the cult of Demeter [and Persephone] was established in various cities of Crete' (cf. R.F. WILLETTS [supra n. 140], p. 148-152). 
element, it was possibly early. But more remarkable is the fact that we now seem to have evidence for such a cult associated specifically with a male deity, namely one who was ultimately to emerge as a very important god.

Given the importance, then, of the cult of Cretan Zeus, can some of this importance be attributed already to an early date ? Indeed the evidence for the possible date of the cult of Zeus on Mt Iouktas is no less important. It is of greatest interest, therefore, that the excavator informs us that, like much of the evidence in general, in particular the offeringtable of greenish stone built into the altar "belongs to the first phase of the sanctuary' 143 , and that the treasure of bronze double axes belongs to 'the Old Palace stratum'144. We may therefore now also envisage the existence of an independent, specific cult of Cretan Zeus going back to at least the MM IA period. This too has significant implications. It has, for instance, a direct bearing on the age-old question of 'the One' and 'the Many'. In other words, was there a single deity in the earliest period of Minoan culture, a Great Mother Goddess, who continued to dominate Minoan religion to almost the end - with individual deities coming into existence, or at least into prominence only towards or at the end of the Bronze Age, as many critics still seem to believe ${ }^{145}$, or must we now consider the possibility that there were important individual deities who had specific cults of their own already at the beginning of the MM period, if not indeed earlier? And must we not also begin to rethink the problem of the rôle of the male element in Minoan religion ${ }^{146}$ ? These are intriguing questions, which the new evidence from the peak sanctuary on Mt Iouktas raises.

143 Alexandra KARETSOU (supra n. 74), p. 145. The altar itself can therefore scarcely have been built at a later date.

144 Ibid, p. 146.

145 MATZ held that only at the beginning of the LM period did individual deities begin to differentiate themselves from the one principal deity who had prevailed hitherto.

146 It is perhaps worth recalling here FAURE's conclusion (expressed just before the latest excavations at Mt Iouktas began) that, upon careful examination of the evidence, he found it impossible to agree with the view of modern interpreters that the core of Minoan religion was formed by a Great Mother Goddess as the symbol of creativity in Nature, accompanied by a young god, her son and paramour, who dies shortly after their marriage and then in spring is reborn. As he notes, 'she is accompanied by a god, but sometimes the god forces the goddess into the background' (P. FAURE [supra n. 16], p. 304305). 
There are, however, additional reasons for regarding the cult of Cretan Zeus as being early. These derive from consideration of the close connection between 'Minos', the dynastic term for the Minoan rulers, and Zeus ${ }^{147}$. It revolves around the idea that Minos, as ruler of Knossos, was an enneoros, i.e., an 'eight-year' king, who 'held converse with Zeus' every ninth year ${ }^{148}$. Faure has drawn attention to the extensive degree to which this eight-year phenomenon appears in later Greek culture, and has also shown convincingly how this was derived from the convergence of solar and lunar phenomena - i.e., when the sun and the moon returned to the same place in the sky where they had originated in other words, determining when the end of the solar year coincided with the end of the lunar year ${ }^{149}$. As he explains, "The eight-year cycle of 99 months of alternately 29 and 30 days and the necessary intercalations was the only vehicle by which to bring the seasons more or less into conjunction with each other, i.e., the sun and the moon, and thereby establish harmony between the course of Nature and the life of the community, whose representative is the king'. Moreover, Faure thinks that it was 'Minoan Crete' that developed this system, namely as distinct from the systems in the Semitic region of the eastern Mediterranean and in Egypt, and that Minoan Crete then bequeathed this system to the whole of the Aegean, where it was readily taken up in subsequent periods. He also notes that, thanks to the fact that the Minoan economy was based predominantly on agriculture and seafaring, it was the primary task of the ruler and the priests who assisted him to determine the calendar. To this end, they were assisted by such natural observatories as the peak sanctuaries and the Cave of Zeus on Mt Ida, as well as by the strictly east-facing chapels in the 'palaces' (they should really be called temples). Myth too played a rôle, in particular the legends connected with the birth of Zeus, with which Capricorn, the Little Bear, Aries and Scorpion were associated in the Classical period, as well as the stellar orb which served as his toy ${ }^{150}$. The strong association of the cave on Mt Ida with Zeus and the legends which link Pythagoras with this place are but later reflections of the early importance of Zeus in the above context ${ }^{151}$. The evidence from the latest excavations on $\mathrm{Mt}$

147 For an initial discussion of this subject, cf. E.F. BLOEDOW and C. BJÖRK (supra n. 52).

148 Odyssey, XLX, 179.

149 P. FAURE (supra n. 16), p. 264-267.

150 Ibid., p. 267.

151 Ibid., p. 267-270. 
Iouktas, accordingly, seems to be in acceptable agreement with Faure's reconstruction. And the early (MM I) date which emerges from these excavations highlights the significance of the cultural developments which we have discussed. It will be interesting to see how further archaeological investigation will expand our horizons in this respect.

University of Ottawa

Edmund F. BLOEDOW

Faculty of Arts

Classical Studies

30 Stewart Street

OtTaWA, CANADA K1N 6N5 


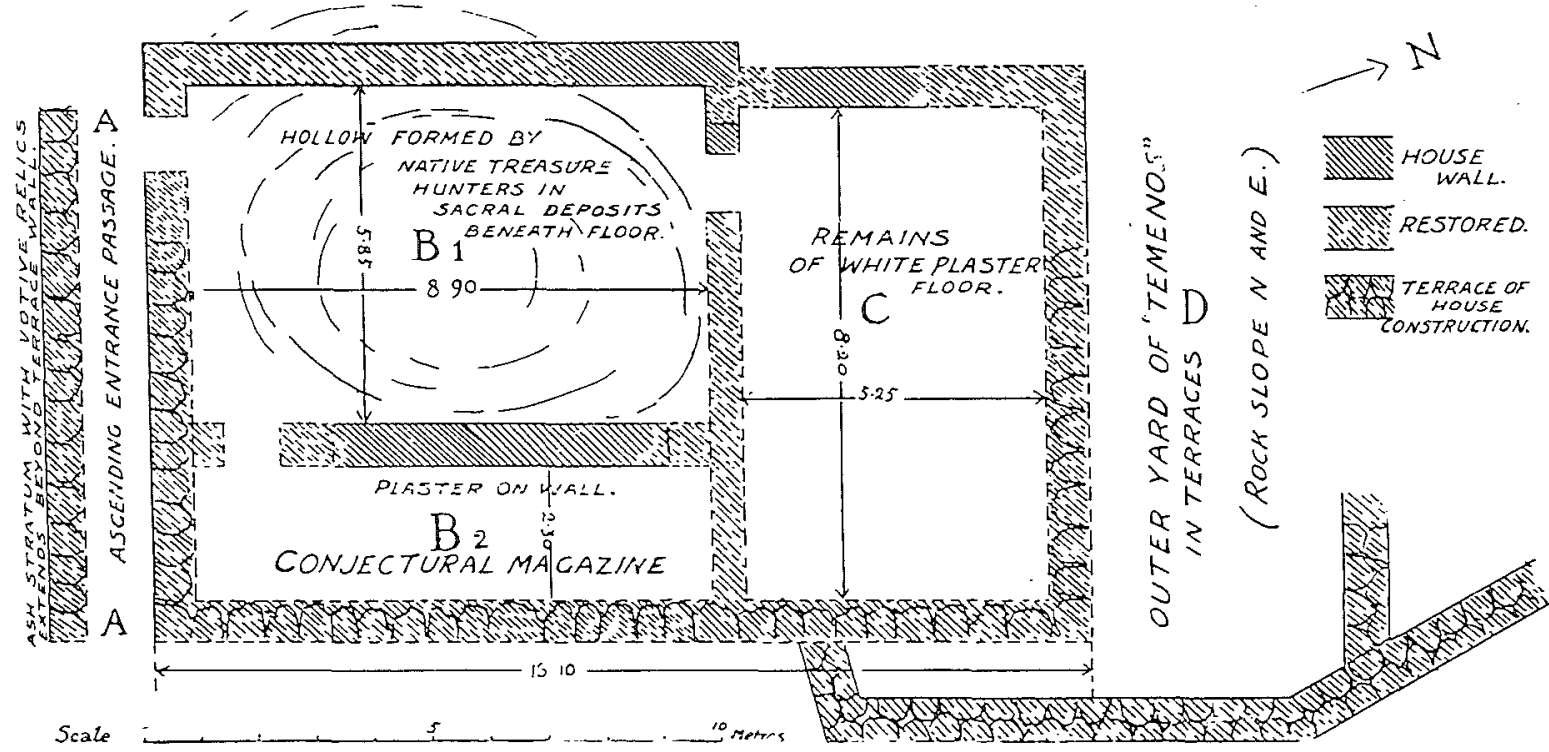

Fig. 1: Plan of the early sanctuary on Mt Iouktas (after Evans). 


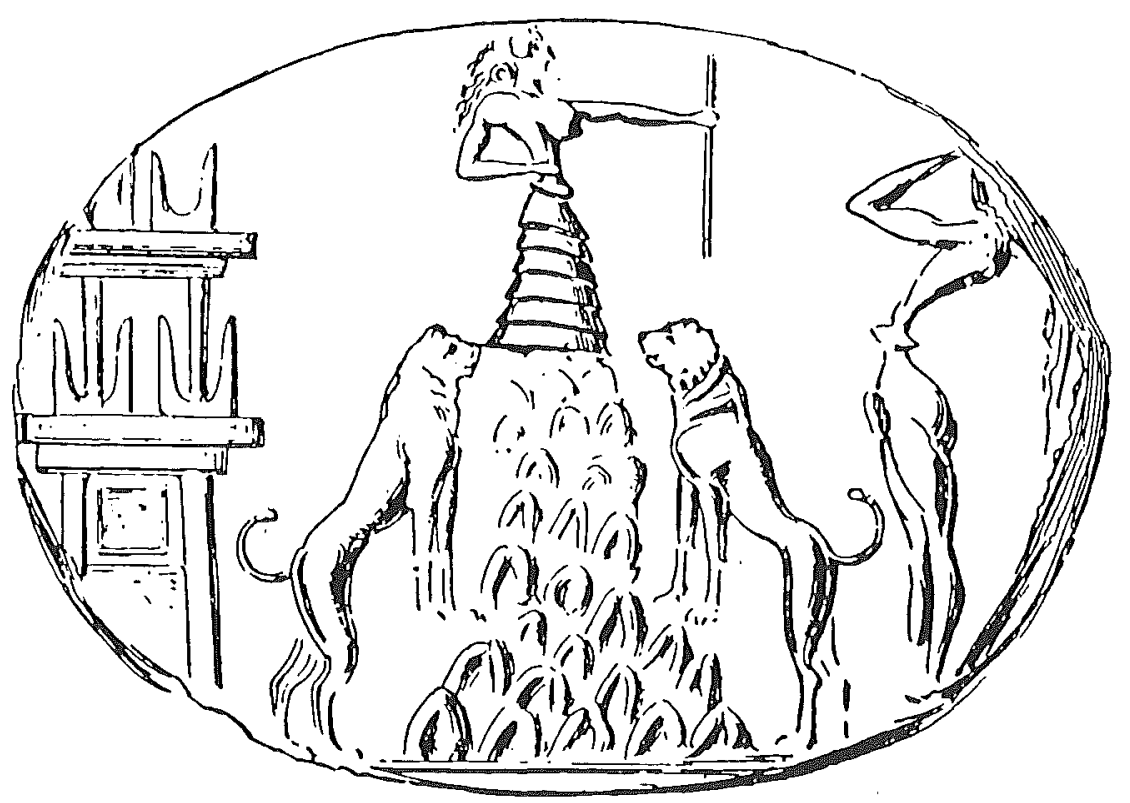

Fig. 2: Seal impression from the palace of Knossos : Mother of the Mountains'.

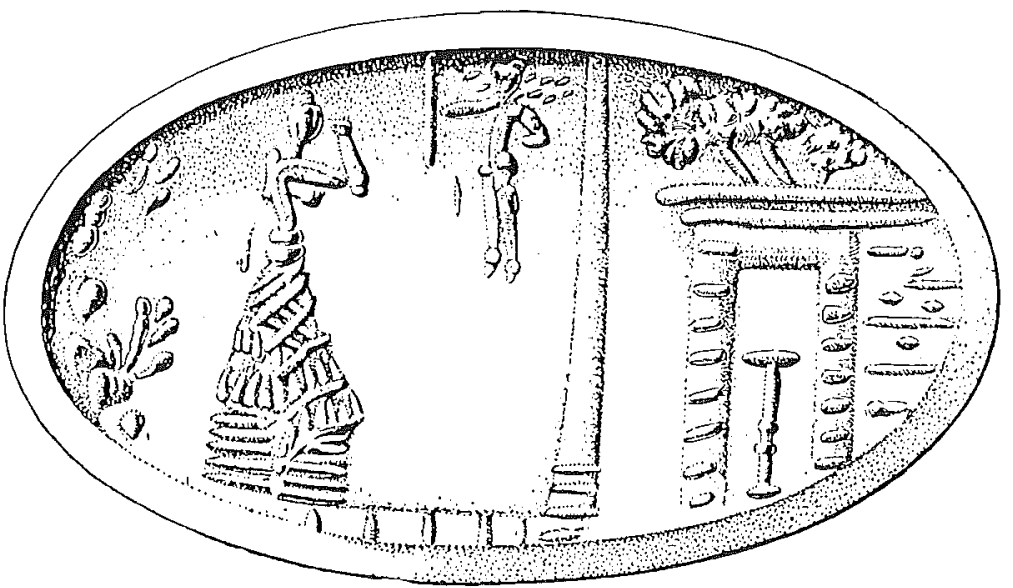

Fig. 3: Gold signet ring from the palace of Knossos : Cult scene. 


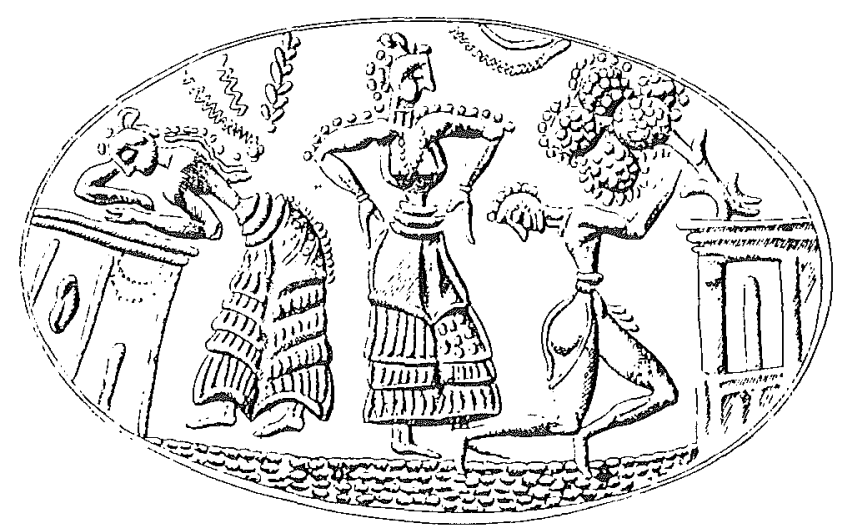

Fig. 4: Gold signet ring from Mycenae : Cult scene.

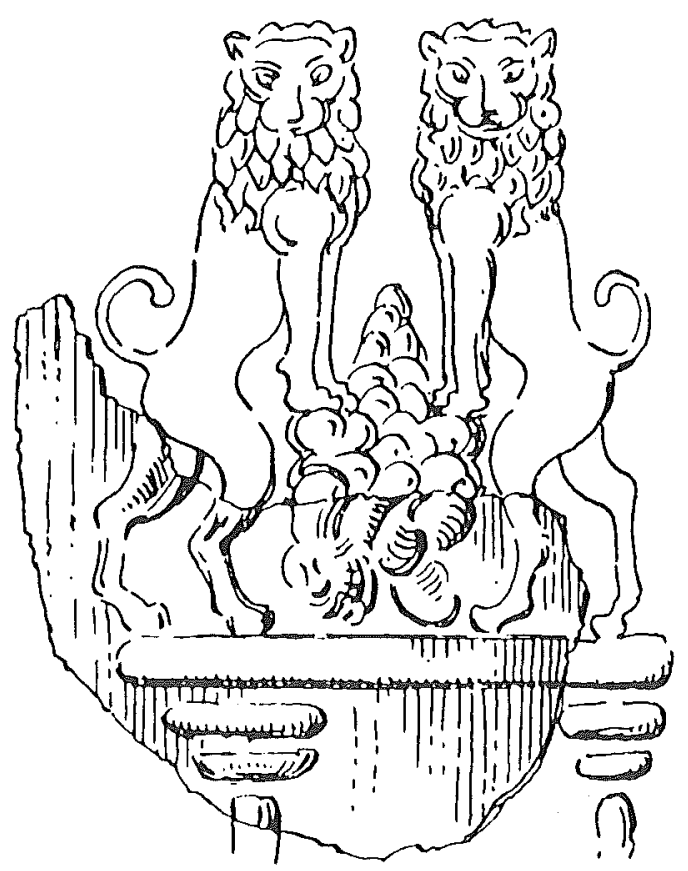

Fig. 5: Sealing from the Little Palace at Knossos : Heraldic lions. 


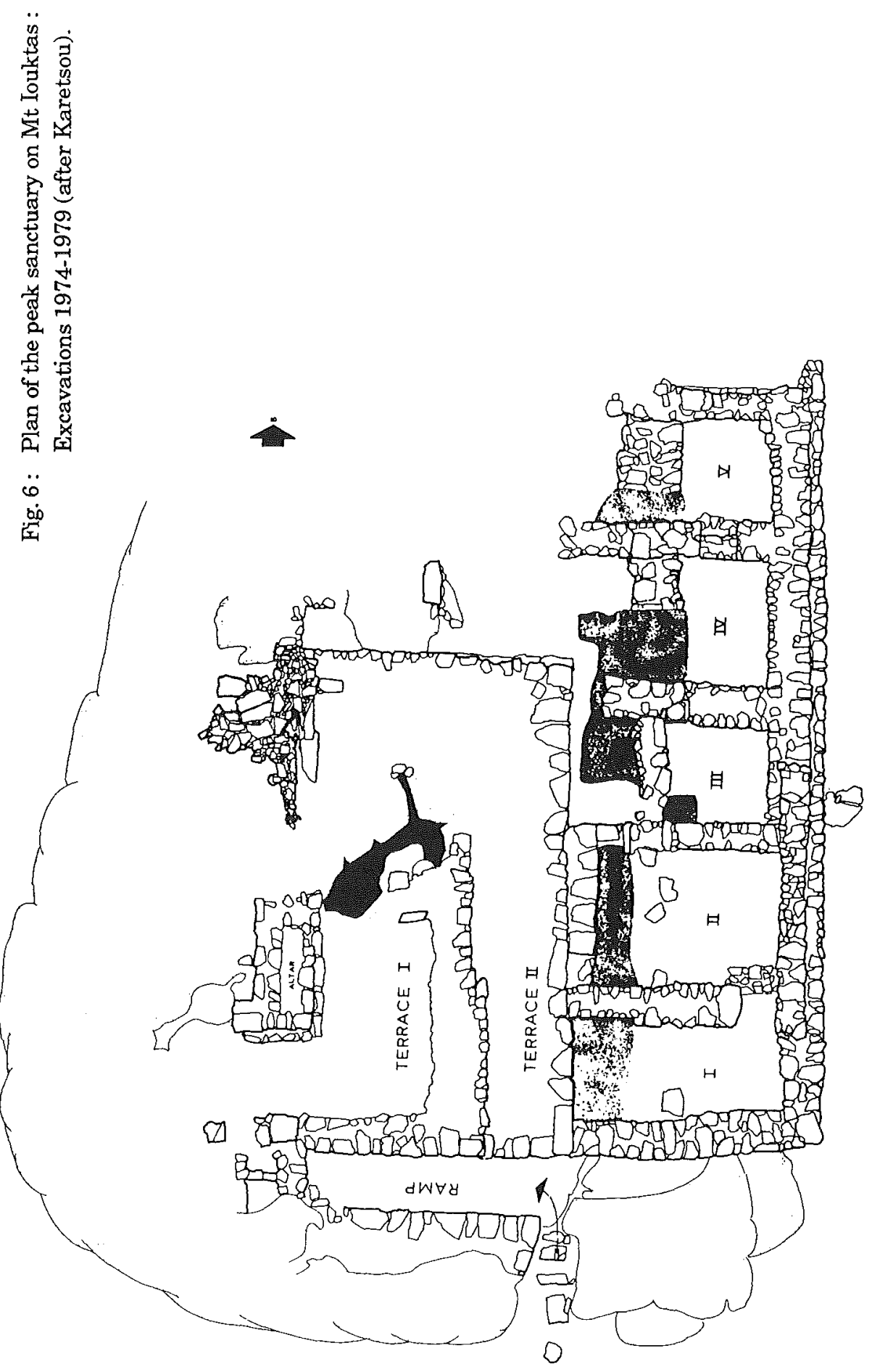




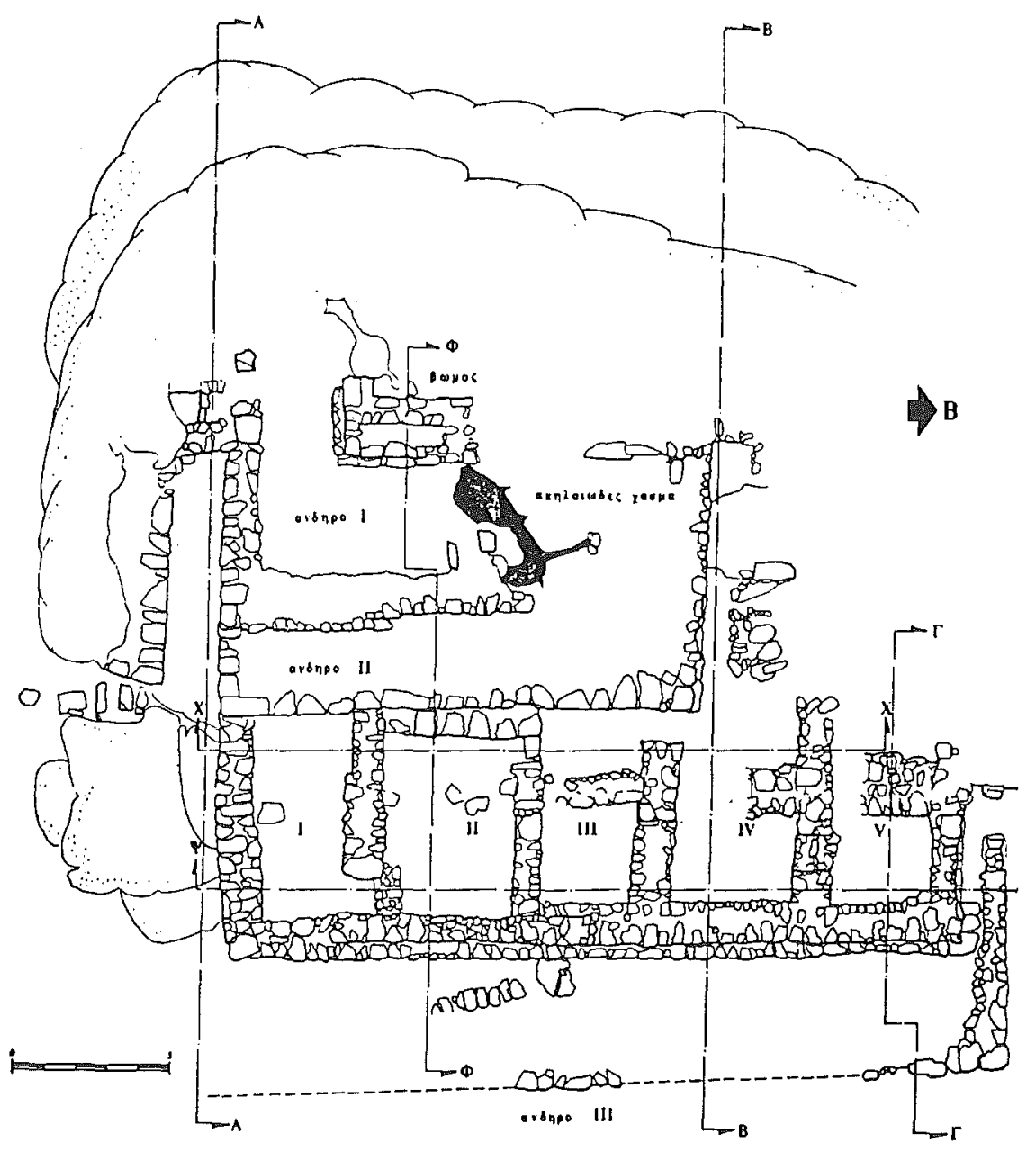

Fig. 7: Plan of the peak sanctuary on Mt Iouktas :

Later excavations showing additional terraces (after Karetsou). 


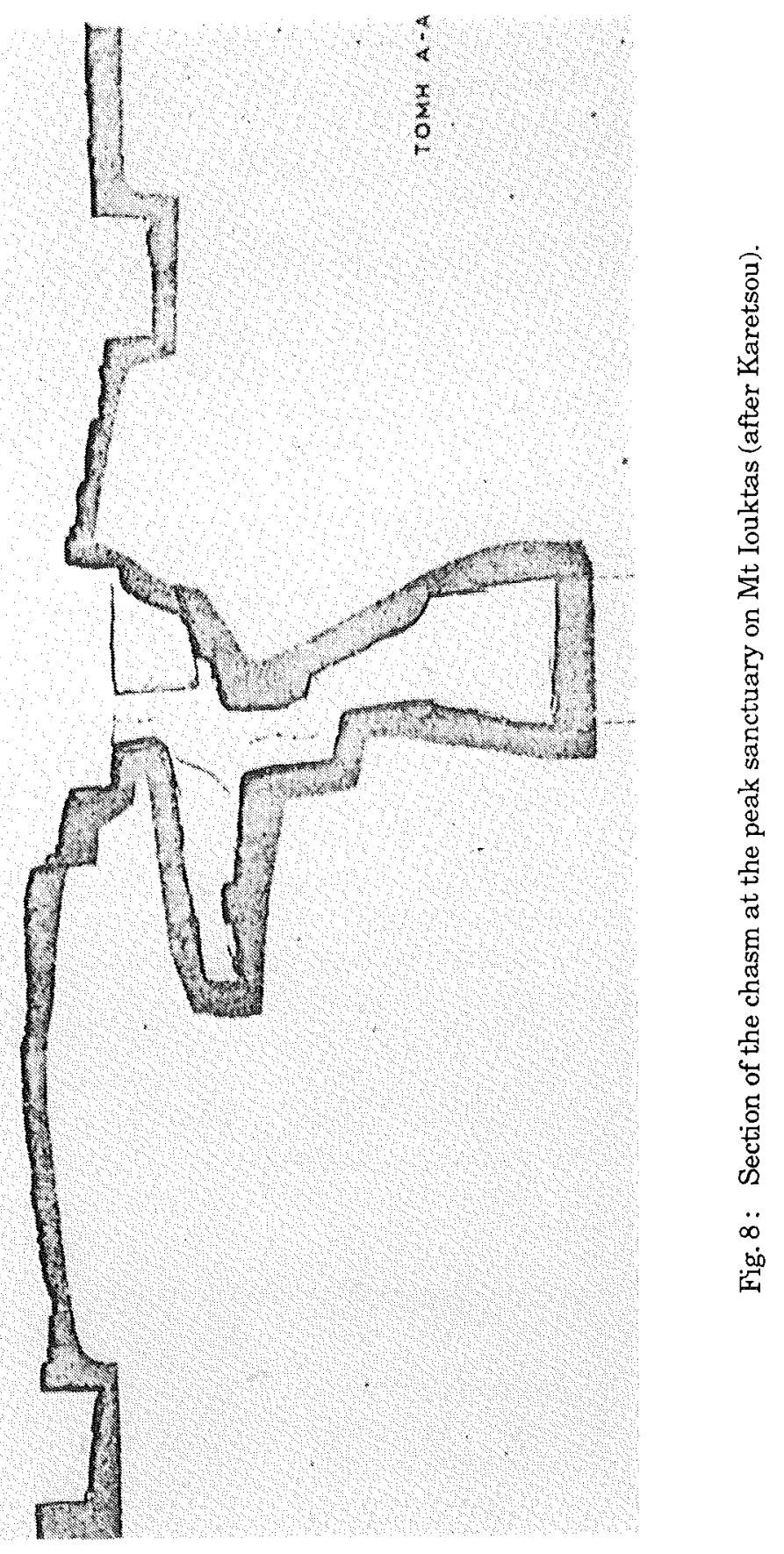

